\title{
IMPACTS OF GEOMORPHIC DISTURBANCES ON PLANT COLONIZATION IN EBBA VALLEY, CENTRAL SPITSBERGEN, SVALBARD
}

\author{
MONIKA STAWSKA \\ Institute of Geoecology and Geoinformation, Adam Mickiewicz University in Poznań, Poland
}

Manuscript received: September 1, 2016

Revised version: January 30, 2017

\begin{abstract}
STAWSKA M., 2017. Impacts of geomorphic disturbances on plant colonization in Ebba Valley, central Spitsbergen, Svalbard. Quaestiones Geographicae 36(1), Bogucki Wydawnictwo Naukowe, Poznań, pp. 51-64, 3 figs, 3 tables.

ABSTRACT: Global warming observed nowadays causes an increase in geomorphic activity in polar regions. Within the areas influenced by cold climatic conditions, relief dynamics and vegetation development are the main landscape shaping processes. The study is limited to the Ebba Valley $\left(78^{\circ} 43^{\prime} \mathrm{N} ; 16^{\circ} 37^{\prime} \mathrm{E}\right)$ in central Spitsbergen (Svalbard), where geomorphologic observations and vegetation sampling were conducted in 2007. The valley was divided into three zones differentiated by dominating geomorphic activity and stability of deposits. The settlement and the evolution of plant cover have been documented there. The main factors that control well developed vegetation cover within raised marine terraces are frost heave and solifluction. In deeper parts of the valley, aeolian processes dominate and high differentiation of microsite conditions causes high variability in plant coverage. The area close to the Ebba glacier marginal zone is characterized by initial stages of plant colonisation where disturbance to vegetation is mainly caused by hydrological processes.
\end{abstract}

KEY WORDS: plant colonization; glacier foreland; climate change; Spitsbergen

Corresponding author: mstawska@amu.edu.pl

\section{Introduction}

The on-going climate change is expected to be most pronounced in high latitudes (ACIA 2004) and greatly affect tundra ecosystems (Forbes et al. 2010), which are considered as vulnerable. The average Arctic surface temperatures have been rising faster than those of the rest of the Northern Hemisphere (IPCC 2013) and therefore there is expected further increase of growth, abundance and cover expansion of arctic woody plants (Forbes et al. 2010, Natali et al. 2012) as well as changes in the structure of the Arctic tundra
(Chapin et al. 2005). Since global warming is now one of the main factors affecting tundra ecosystems (Zwoliński, Dobiński 2008), it is important to investigate not only vegetation establishment on recently quite rapidly deglaciated areas but also plant responses to changing habitat conditions, especially to intensified geomorphic activity reported from periglacial environments (Zwoliński et al. 2008a, Mercier 2009).

Plant succession has long been the object of research in the Arctic, yet many of the studies dealing with the subject are focusing on the mechanism of plant succession (i.e. Chapin et al. 1994). A 
number of studies review the succession patterns (Churchill and Hanson 1958, Hodkinson et al. 2003, Jones and Henry 2003), or relationships between plant cover and microrelief (Anderson and Bliss 1998, Cannoe et al. 2004, Jónsdóttir 2005). Plant colonisation on newly exposed terrain is considered to be the main factor in stabilising glacier foreland deposits, but it was also proved that the influence is reciprocal: habitat disturbances on glacier forelands play a significant role in determining the rate of colonisation, distribution of pioneer species, as well as high species diversity in the initial phase of succession (Matthews 1992, Komárková 1993, Prach and Rachlewicz 2012). Physical stress to plants is one of the main mechanisms determining the course of succession while the intensity of surface disturbance determines its starting point (Connell and Slatyer 1977). Current vegetation structure and relief shape represent temporary equilibria which are slowly developing and adapting to environmental stresses until the next disturbance destroys them to different rates and initiates development of a new equilibrium state (Gutierrez and Fay 1980). Such cycles may be accelerated due to climate change, and therefore more attention should be paid to how arctic vegetation varies in relation to relief dynamics in various spatial scales and in changing environment (Prach et al. 2012).

The area of glacier forelands is increasing and undergoes intense modifications caused mainly by two types of dynamics: the above mentioned plant colonisation and active remodelling of glacial deposits (Szpikowski et al. 2014). On Spitsbergen, valley glaciers have been retreating since the end of the Little Ice Age which occurred 600-100 years ago (Kłysz et al. 1989 Rachlewicz et al. 2007) and its maximum occurred on Svalbard in the 1900s (Fleming et al. 1997, Moreau et al. 2008). It means that the glacier retreated there relatively recently and within the areas affected by that cold climatic period, the vegetation may have started to re-establish only some decades ago (Svoboda and Henry 1987). An example of such environment can be Ebba Valley.

The aims of this paper are to analyze the valley of Ebba glacier in central Spitsbergen in terms of (1) recognizing factors that control vegetation cover development in periglacial zone and (2) investigating the spatial differentiation of this cover. The next step is (3) the analysis of plant cover density and its vertical structure on the valley bottom of increasing age and (4) determination of species composition and successional stages along Ebba Valley.

\section{Study area}

The study was conducted in Ebba Valley which is located in the central part of Spitsbergen (Svalbard Archipelago, Fig. 1). The valley is situated on the eastern coast of Petunia Bay which is the northern end of Billefjord - a northeastern Isfjord branch $\left(78^{\circ} 43^{\prime} \mathrm{N}, 16^{\circ} 37^{\prime} \mathrm{E}\right)$ (Rachlewicz et al. 2013).

The bedrock geology is dominated by dislocations along the Billefjorden Fault Zone of which most characteristic formations are metamorphic and carbonate outcrops (Rachlewicz et al. 2013). Sediments are mainly of marine, glacial, slope and fluvial origin (Dallmann et al. 2004). Permafrost is present in the soils of the study area and active layer can reach up to $1.2 \mathrm{~m}$ thickness during summer period (Rachlewicz and Szczuciński 2008, Mazurek et al. 2012).

Despite of being generally influenced by the warm West Spitsbergen Current, the climate of the study area is characterized by quasi-continental features such as higher temperatures in the ablation period $\left(1-2^{\circ} \mathrm{C}\right.$ more in comparison to western part) and very low precipitation throughout the year (not exceeding $60 \mathrm{~mm}$ during summer), which is characteristic for the central and eastern parts of the island (Rachlewicz 2003, Rachlewicz and Styszyńska 2007, Rachlewicz et al. 2013, Nordli et al. 2014).

According to the bioclimatic classification made by Elvebakk (1999), Ebba Valley is located in middle Arctic tundra zone. The vegetation within the study site is classified as the high Arctic Dryas octopetala tundra type (Rønning 1996), where the dominant species are polar willow (Salix polaris) and white dryas (Dryas octopetala).

\section{Methods}

\section{Location of sampling sites}

From the moraine edge, westward for $5 \mathrm{~km}$ to the coast of Petunia Bay, seventeen sites were 


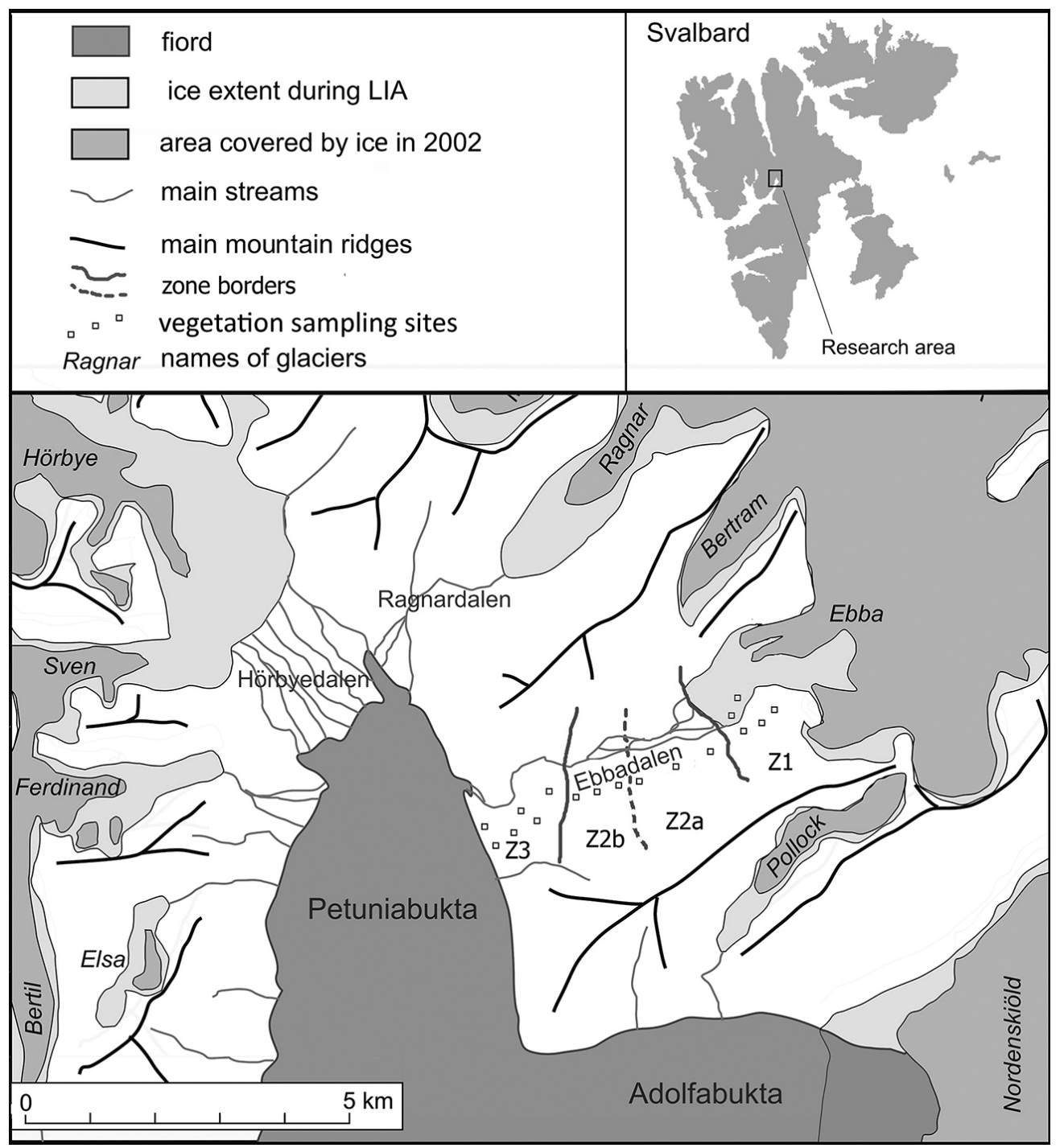

Fig. 1. Study site location and its division into zones of different geomorphic activity (modified after Rachlewicz et al. 2007).

chosen for vegetation sampling along the longitudinal profile of Ebba Valley (Fig. 1) at the distance of 200 or $400 \mathrm{~m}$ from each other, depending on variability of vegetation cover. Differences of microsite conditions such as type of sediments and their stability, geomorphic processes and age of surface were taken into account when choosing sites (Tab. 1). Then, quadrate sample plots were established within each site. Such linear type of sampling, from glacier marginal zone to the mouth of the valley, gives an adequate means to investigate the successional stages of vegetation which are the consequence of glacier retreat and soil development through time (Moreau et al. 2005) while random distribution of sample plots within sites makes it possible to assess the influence of different types of geomorphic activity on the development of plant cover.

\section{Geo-botanical environment}

Ebba valley, stretching from east to west, has a form of a "funnel" from which waters are quickly discharged (Kostrzewski et al. 1989, Szpikowski et al. 2014, Rachlewicz et al. 2016). Geomorphological forms of such type are characterized by the dominance of dry and very dry habitats. Snow thickness during winter is rather low. The vegetation is usually fragmentary due to abrasion and dominated by communities with a large proportion of Saxifraga oppositifolia, Dryas octopetala, Cassiope tetragona, Carex rupestris and Deschampsia alpina (Prach et al. 2012). 
Table 1. Physical environment of delimited zones in Ebba Valley.

\begin{tabular}{|c|c|c|c|c|c|c|}
\hline Zone & Site number & Terrain age & $\begin{array}{l}\text { Geological } \\
\text { substrate }\end{array}$ & Landform & Dominant processes & $\begin{array}{c}\text { Stability of } \\
\text { deposits }\end{array}$ \\
\hline $\mathrm{Z1}$ & I-III & $\begin{array}{l}\text { Holocene, } \\
\text { with Precam- } \\
\text { brian rock } \\
\text { outcrops }\end{array}$ & $\begin{array}{l}\text { till, deposits of grav- } \\
\text { itational, aeolian } \\
\text { and fluvial origin }\end{array}$ & outwash plain & $\begin{array}{l}\text { runoff, flooding, wash- } \\
\text { out, channel bank } \\
\text { erosion, debris flow, } \\
\text { aeolian accumulation }\end{array}$ & $\begin{array}{l}\text { high insta- } \\
\text { bility }\end{array}$ \\
\hline $\mathrm{Z1}$ & IV-V & Holocene & $\begin{array}{l}\text { till, deposits of grav- } \\
\text { itational, aeolian } \\
\text { and fluvial origin }\end{array}$ & $\begin{array}{l}\text { area of contact } \\
\text { of alluvial fan } \\
\text { and outwash } \\
\text { plain }\end{array}$ & $\begin{array}{l}\text { runoff, flooding, } \\
\text { wash-out, channel } \\
\text { bank erosion, debris } \\
\text { flow, fluvioglacial and } \\
\text { aeolian accumulation, } \\
\text { landslides }\end{array}$ & $\begin{array}{l}\text { high insta- } \\
\text { bility }\end{array}$ \\
\hline $\mathrm{Z} 2 \mathrm{a}$ & VI-VIII & Holocene & $\begin{array}{l}\text { till, deposits of grav- } \\
\text { itational, aeolian } \\
\text { and fluvial origin }\end{array}$ & $\begin{array}{l}\text { rear slope of } \\
\text { marine terraces }\end{array}$ & $\begin{array}{l}\text { aeolian accumulation, } \\
\text { deflation, debris flow, }\end{array}$ & $\begin{array}{l}\text { average sta- } \\
\text { bility, locally } \\
\text { unstable }\end{array}$ \\
\hline $\mathrm{Z} 2 \mathrm{~b}$ & IX-XI & $\begin{array}{l}\text { Holocene/ } \\
\text { late pleisto- } \\
\text { cene }\end{array}$ & $\begin{array}{l}\text { marine deposites, } \\
\text { deposits of gravita- } \\
\text { tional, aeolian and } \\
\text { fluvial origin }\end{array}$ & $\begin{array}{l}\text { raised marine } \\
\text { terraces remod- } \\
\text { elled by glacier } \\
\text { transgression }\end{array}$ & $\begin{array}{l}\text { deflation, debris flow, } \\
\text { surface runoff }\end{array}$ & $\begin{array}{l}\text { average sta- } \\
\text { bility, locally } \\
\text { unstable }\end{array}$ \\
\hline Z3 & XII-XVII & Holocene & $\begin{array}{l}\text { marine and aeolian } \\
\text { deposites }\end{array}$ & $\begin{array}{l}\text { raised marine } \\
\text { terraces }\end{array}$ & $\begin{array}{l}\text { solifluction, frost heave, } \\
\text { surface runoff }\end{array}$ & rather stable \\
\hline
\end{tabular}

At each site the age of deglaciated terrain and destructive factors for vegetation were documented, along with other environmental variables such as soil type and its permeability, exposition, wind exposure conditions and stability of deposits. Terrain age and geomorphic processes were considered as the main factors affecting plant colonisation, while other environmental factors as secondary influence variables for plant cover development. The collected data and recognition of dominant geomorphic processes (Kostrzewski et al. 2006, Rachlewicz et al. 2012) were the basis for dividing the Ebba Valley into three zones (Fig. 1) differentiated in terms of vegetation cover characteristics. Zone 1 is the youngest part of the valley. The terrain is constantly reworked by glacier and snow melting water. Zone 2 was internally divided into two sub-zones on the basis of dominating sediment type. Zone 3, i.e. raised marine terraces is the oldest part of the valley (more than 5000 years old, according to deglaciation and sea level changes dating e.g. by Kłysz et al. 1989, Long et al. 2012, Rachlewicz and Szczuciński 2013).

\section{Vegetation sampling}

Vegetation sampling was conducted in 2007 on total 425 quadrat sampling plots: $251 \times 1 \mathrm{~m}$ plots located in each of seventeen study sites along the Ebba Valley. Six sites were located in Zone 2 and Zone 3, 5 were located in Zone 1. Quadrate sample plots within different sites were established to quantify the distribution of vascular plant species among microsites (quadrates) within each site and to register species diversity. The quadrats were randomly placed, regardless of microtopography, within a study site. Plant cover, plant size, frequency, and density were estimated for each species. Cover estimates of lichens and bryophytes, cryptogamic crust, percentage of bare ground and sediment type were recorded. Additionally, five quadrat plots from each site were examined in more detail: the number of shoots of particular species was counted. The density of each species was expressed in amount of aboveground shoots/0.5 $\mathrm{m}^{2}$, in the case of vegetative reproduction, as separate individuals were considered plants having their own root system (cf. Robotnov 1964). Species encountered were divided by occurrence frequency in sample plots.

Nomenclature for plant names follows Rønning 1996 and Elven and Elvebakk 1996.

\section{Results}

\section{Habitat disturbances determining plant colonisation}

The set of geomorphological processes in the vicinity of east coast of Petuniabukta (Kostrzewski et al. 2006, Rachlewicz et al. 2012) having crucial 
influence on vegetation cover within three delimited in the Ebba Valley zones are as follows:

1. Zone 1 (Z1) - upper stream: runoff zone. Located in the vicinity of glacier marginal zone. Dominant processes: ice and snow melting water eroding outwash plain and surrounding slopes.

2. Zone $2(\mathbf{Z} 2)$ - middle stream: aeolian activity zone. Divided into two subzones: Z2a where accumulation processes dominate: deposition of fine textured material and gravity flow deposits, $\mathbf{Z 2} \mathbf{b}$ where erosion processes dominate: deflation of fine textured material, drying impact of wind.

3. Zone $3(\mathbf{Z 3})$ - lower stream: frost heave and solifluction zone. Located within raised marine terraces in the mouth of the valley.

Z1 proves to be most disturbed by geomorphic processes. Multiple seasonal channels cut into the deposits causing wash-out of sediments and plants or the sediment load is accumulated and covers vegetation. Similar effects occur due to spring floodings. In the area of contact with lower slopes of alluvial fans, multiple landslides destroying plant cover occur. Within Z2 and Z3 the geomorphic processes are less intensified and of less abrupt character.

\section{Plant cover: percent space occupancy}

In $\mathrm{Z} 1$ plant coverage is between $1-10 \%$ and only locally exceeds this value. In some plots it is near $25 \%$, but only at the spots sheltered by boulders of crystalline rock, preventing wash-out.

$\mathrm{Z} 2$ is characterized by high variability in plant coverage. The lowest, not exceeding $10 \%$ occurs within the exposed ridges of raised marine terraces. In terrain depressions sheltered from the wind and being local deposition sites for fine-textured material, the plant coverage may reach up to $75 \%$. On the slightly sloping area of the rear slope of marine terraces and flat contact area to the outwash plain, the coverage is usually about $25 \%$, locally reaching $50 \%$.

Within Z3, the oldest part of the valley which was not under the direct influence of Ebba Glacier transgression during the LIA, plant cover is well developed and the percentage of covered ground is often close to $100 \%$. High percentage of bare ground is characteristic only for exposed ridge crests where deflation has a significant impact.

\section{Species diversity}

A total of 22 vascular plant species were recorded in the plots (Tab. 2). Bryophytes and lichens were also present, but only their cover percentage was estimated. Species richness increased with increasing relief age and distance from the glacier front. Within the youngest and most disturbed Zone 1, 7 species were documented, of which only 4 were encountered in the vicinity of glacier marginal zone. In Z2, where deposits were more stable and locally favourable moist conditions were recorded, 12 species were documented, of which 3 were not common for the two subzones: Minuartia sp. and Potentilla pulchella were encountered only within subzone $Z 2 \mathrm{~b}$. The oldest part of the valley, $\mathrm{Z3}$, was characterized by the highest species diversity: 20 species were documented.

Only three species i.e. Saxifraga oppositifolia, Bistorta vivipara and Salix polaris occurred in all the sites along the transect. All the zones were differentiated in terms of species occurrence and sociability within sample plots (Table 3).

Saxifraga oppositifolia, Bistorta vivipara and Salix polaris were most abundant in zones 2 and 3, along with absent in Z1 Dryas octopetala. Similar, but lower occurrence frequency in zones 2 and 3 had also Draba corymbosa, Minuartia biflora, Potentilla pulchella and Silene furcata. The other common for all zones species were more frequently encountered within sample plots of Zone 3. Only three of documented species are specialised ones. Dryas octopetala and Potentilla pulchella preferred calciferous substrates, while Saxifraga aizoides demanding higrophilous habitat was documented only along the banks of surface runoff channels. Most common and dominant species i.e. Saxifraga oppositifolia, Dryas octopetala and Salix polaris were forming two different growth forms depending on habitat conditions. If the percent of plant cover was low, Dryas octpetala and Salix polaris formed cushions. Whenever these species were growing in dense plant cover they formed wide patches or carpets but without superseding other species. Saxifraga oppositifolia preferred a prostrate form when colonizing areas where plant cover did not exceed $30 \%$ and in dense plant cover it formed carpets accompanied by Dryas octpetala and Salix polaris. In favourable moisture conditions and where plant cover was on the average level, it preferred a cushion form. 
Table 2. Vascular plants documented in Ebba Valley within particular study sites.

\begin{tabular}{|c|c|c|c|c|c|c|c|c|c|c|c|c|c|c|c|c|c|c|c|c|c|c|c|c|c|}
\hline \multirow{3}{*}{ Zone } & \multirow{3}{*}{$\begin{array}{c}\text { Site } \\
\text { number }\end{array}$} & \multirow{3}{*}{$\begin{array}{c}\text { Rate of } \\
\text { percentage } \\
\text { cover }\end{array}$} & \multirow{3}{*}{$\begin{array}{l}\text { Dominant } \\
\text { processes }\end{array}$} & \multicolumn{22}{|c|}{ Species } \\
\hline & & & & 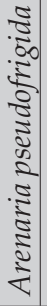 & 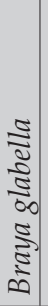 & 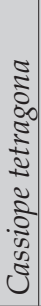 & 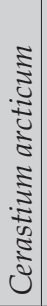 & 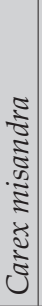 & 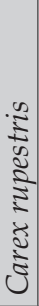 & 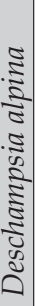 & \begin{tabular}{|c|} 
\\
$\frac{1}{2}$ \\
$\frac{1}{2}$ \\
$\frac{1}{2}$ \\
$\frac{1}{1}$
\end{tabular} & $\begin{array}{l}5 \\
0 \\
0 \\
\text { है } \\
5 \\
0 \\
0 \\
0 \\
0 \\
0 \\
0\end{array}$ & $\begin{array}{l}\frac{3}{5} \\
\frac{5}{0} \\
5 \\
0 \\
0 \\
0 \\
5 \\
5 \\
0 \\
0\end{array}$ & 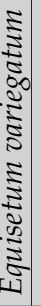 & | & 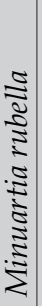 & 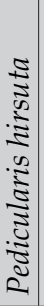 & 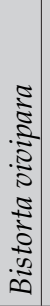 & 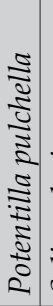 & 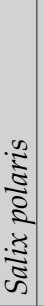 & 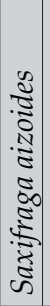 & 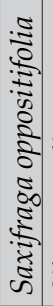 & 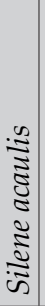 & $\begin{array}{c} \\
\\
\frac{5}{5} \\
\frac{5}{5} \\
\frac{5}{5} \\
\frac{\Xi}{5} \\
\frac{5}{\omega}\end{array}$ & 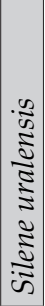 \\
\hline & & & & \multicolumn{22}{|c|}{ Occurence } \\
\hline 1 & I-III & I-III: $1-10 \%$ & $\begin{array}{l}\text { runoff, flood- } \\
\text { ing, wash- } \\
\text { out, channel } \\
\text { bank erosion, } \\
\text { debris flow, } \\
\text { aeolian accu- } \\
\text { mulation }\end{array}$ & & & & & & & & & & & & & & & + & & + & + & + & & & \\
\hline 1 & IV-V & IV-V: $1-10 \%$ & $\begin{array}{l}\text { runoff, flood- } \\
\text { ing, wash- } \\
\text { out, channel } \\
\text { bank erosion, } \\
\text { debris flow, } \\
\text { fluvioglacial } \\
\text { and aeolian } \\
\text { accumulation, } \\
\text { landslides }\end{array}$ & & & & & & & + & & & & & & & & + & & + & + & + & & + & + \\
\hline $2 \mathrm{a}$ & VI-VIII & $\begin{array}{c}\text { VI: }<1 \%, \\
\text { VII: } 1-10 \% \\
\text { VIII: } 10-25 \%\end{array}$ & $\begin{array}{l}\text { aeolian ac- } \\
\text { cumulation, } \\
\text { deflation, } \\
\text { debris flow, }\end{array}$ & & + & & + & & & + & & + & + & & & & & + & & + & & + & & + & \\
\hline $2 b$ & IX-XI & $\begin{array}{c}\text { IX: } 10-25 \% \\
\text { X, XI: } 1-10 \%\end{array}$ & $\begin{array}{l}\text { deflation, } \\
\text { debris flow, } \\
\text { surface runoff }\end{array}$ & & + & & + & & & + & & & + & & + & + & & + & + & + & & + & & + & \\
\hline 3 & $\begin{array}{l}\text { XII- } \\
\text { XVII }\end{array}$ & $\begin{array}{c}\text { XIII: } 25-50 \% \\
\text { XII, XIV-XVII: } \\
\text { 75-100\% }\end{array}$ & $\begin{array}{l}\text { solifluction, } \\
\text { frost heave, } \\
\text { surface runoff }\end{array}$ & + & + & + & & + & + & + & + & + & + & + & + & + & + & + & + & + & & + & + & + & + \\
\hline
\end{tabular}

\section{Percent participation and abundance}

Species percent participation in total flora of the research area compared with shoot density made it possible to distinguish three groups of species:

- of participation not exceeding $10 \%$, as Arenaria pseudofrigida, Cassiope tetragona, Cerastium arcticum, Deschampsia alpina, Draba sp., Equisetum variegatum, Minuartia rubella, Minuartia biflora Pedicularis hirsuta, Silene furcata and Silene uralensis, presence of these species (except for Silene furcata) was limited to the youngest marine terraces,

- of participation of $10-25 \%$, as Carex misandra, Carex rupestris and Silene acaulis,

- of participation of more than $40 \%$ in at least ten sample plots, such as: Dryas octopetala, Bistorta vivipara, Salix polaris, Saxifraga oppositifolia and Saxifraga aizoides, all of them (except Saxifraga aizoides) were widespread in the whole valley.

\section{Horizontal and vertical spatial organisation}

In Zone 1, high percent of bare ground was characteristic for all sites. Plant cover formed small patches, or the individuals were growing singly. Most preferred growth form was cushion. Loosely organized assemblages were characteristic for channel banks and the vicinity of large boulders where they found shelter against the wind and wash-out. None of the species was distinctly dominant.

Zone 2a was similar to Zone 1 in terms of spatial organisation. Vegetation was assembled in small patches or individuals were growing 
Table 3. Occurrence frequency (\% of sample plots), sociability, local abundance, ecological indicator value, average shoot density and phytoecological features of species.

\begin{tabular}{|c|c|c|c|c|c|c|c|c|}
\hline \multirow{3}{*}{ Species } & \multicolumn{8}{|c|}{ Feature } \\
\hline & \multicolumn{3}{|c|}{$\begin{array}{c}\text { Occurrence fre- } \\
\text { quency (\% of plots) }\end{array}$} & \multirow[t]{2}{*}{ Sociability $^{1}$} & \multirow{2}{*}{$\begin{array}{l}\text { Local abun- } \\
\text { dance }^{2}\end{array}$} & \multirow{2}{*}{$\begin{array}{c}\text { Ecological } \\
\text { indicator } \\
\text { value }^{3}\end{array}$} & \multirow{2}{*}{$\begin{array}{c}\text { Average } \\
\text { shoot densi- } \\
\text { ty } / 0.5 \mathrm{~m}^{2}\end{array}$} & \multirow{2}{*}{$\begin{array}{l}\text { Soil mois- } \\
\text { ture prefer- } \\
\text { ences }^{4}\end{array}$} \\
\hline & $\mathrm{Z} 1$ & $\mathrm{Z} 2$ & Z3 & & & & & \\
\hline $\begin{array}{l}\text { Arenaria } \\
\text { pseudofrigida }\end{array}$ & - & - & $20 \%$ & growing singly & sparse & euryoic & Z3: 49 & xerophyte \\
\hline $\begin{array}{l}\text { Bistorta } \\
\text { vivipara }\end{array}$ & $100 \%$ & $100 \%$ & $100 \%$ & growing singly & subdominant & euryoic & $\begin{array}{l}\text { Z2: } 54 \\
\text { Z3: } 49\end{array}$ & mesophyte \\
\hline Braya glabella & - & $10 \%$ & $10 \%$ & growing singly & sparse & euryoic & Z2: 2,2 & mesophyte \\
\hline $\begin{array}{l}\text { Cassiope } \\
\text { tetragona }\end{array}$ & - & - & $15 \%$ & carpet forming & dominant & intermediate & Z3: 347,7 & mesophyte \\
\hline $\begin{array}{l}\text { Cerastium } \\
\text { arcticum }\end{array}$ & - & $10 \%$ & - & growing singly & dominant & euryoic & Z2: 8 & mesophyte \\
\hline Carex misandra & - & - & $20 \%$ & tussocks & subdominant & intermediate & Z3: 5 & mesophyte \\
\hline Carex rupestris & - & - & $60 \%$ & tussocks & dominant & intermediate & $Z 3: 37,6$ & mesophyte \\
\hline $\begin{array}{l}\text { Deschampsia } \\
\text { alpina }\end{array}$ & - & $20 \%$ & $5 \%$ & tussocks & dominant & intermediate & $\begin{array}{l}\text { Z2: } 3 \\
\text { Z3: } 0,3\end{array}$ & mesophyte \\
\hline Drabasp. & - & $10 \%$ & $30 \%$ & tussocks & sparse & intermediate & $\begin{array}{l}\text { Z2: } 14 \\
\text { Z3: } 16\end{array}$ & xerophyte \\
\hline $\begin{array}{l}\text { Draba } \\
\text { corymbosa }\end{array}$ & - & $5 \%$ & $5 \%$ & tussocks & sparse & intermediate & $\begin{array}{l}\mathrm{Z} 2: 10 \\
\mathrm{Z} 3: 8\end{array}$ & xerophyte \\
\hline $\begin{array}{l}\text { Dryas } \\
\text { octopetala }\end{array}$ & - & $60 \%$ & $80 \%$ & $\begin{array}{l}\text { large patches or } \\
\text { tussock }\end{array}$ & dominant & intermediate & $\begin{array}{l}\text { Z2: } 170 \\
\text { Z3: } 430\end{array}$ & xerophyte \\
\hline $\begin{array}{l}\text { Equis } \\
\text { varieg }\end{array}$ & - & - & $5 \%$ & growing singly & sparse & intermediate & $\mathrm{Z} 3: 3$ & higrophyte \\
\hline $\begin{array}{l}\text { Minuartia } \\
\text { biflora }\end{array}$ & - & $3 \%$ & $4 \%$ & $\begin{array}{l}\text { growing singly or } \\
\text { forming patches }\end{array}$ & subdominant & intermediate & $\begin{array}{l}\text { Z2: } 0,5 \\
\text { Z3: } 0,9\end{array}$ & mesophyte \\
\hline $\begin{array}{l}\text { Minuartia } \\
\text { rubella }\end{array}$ & - & $1 \%$ & $3 \%$ & growing singly & sparse & intermediate & $\begin{array}{l}\text { Z2: } 0,4 \\
\text { Z3: } 0,4\end{array}$ & xerophyte \\
\hline $\begin{array}{l}\text { Pedicularis } \\
\text { hirsuta }\end{array}$ & - & - & $35 \%$ & growing singly & sparse & euryoic & Z3: 2,1 & mesophyte \\
\hline $\begin{array}{l}\text { Potentilla } \\
\text { pulchella }\end{array}$ & - & $5 \%$ & $5 \%$ & tussocks & dominant & specialised & $\begin{array}{l}\text { Z2: } 0,1 \\
\text { Z2: } 0,1\end{array}$ & xerophyte \\
\hline Salix polaris & $30 \%$ & $80 \%$ & $100 \%$ & $\begin{array}{l}\text { large patches or } \\
\text { tussock }\end{array}$ & dominant & euryoic & $\begin{array}{l}\text { Z1: } 111 \\
\text { Z2: } 347 \\
\text { Z3:578 }\end{array}$ & mesophyte \\
\hline $\begin{array}{l}\text { Saxifraga } \\
\text { aizoides }\end{array}$ & $5 \%$ & - & - & growing singly & subdominant & specialised & Z1:26 & higrophyte \\
\hline $\begin{array}{l}\text { Saxifraga } \\
\text { oppositifolia }\end{array}$ & $100 \%$ & $100 \%$ & $100 \%$ & $\begin{array}{l}\text { carpet forming or } \\
\text { singly }\end{array}$ & dominant & euryoic & $\begin{array}{c}\mathrm{Z1}: 30 \\
\mathrm{Z} 2: 345 \\
\mathrm{Z} 3: 642 \\
\end{array}$ & xerophyte \\
\hline Silene acaulis & - & - & $1 \%$ & growing singly & subdominant & intermediate & Z3: 0,5 & mesophyte \\
\hline Silene furcata & - & $30 \%$ & $25 \%$ & tussocks & sparse & intermediate & $\begin{array}{l}\text { Z2: } 0,7 \\
\text { Z3: } 0,8\end{array}$ & mesophyte \\
\hline Silene uralensis & - & - & $3 \%$ & singly & sparse & intermediate & Z3: 0,2 & mesophyte \\
\hline
\end{tabular}

${ }^{1}$ Reference: Braun-Blanquet 1964, sociability scale.

2 Reference: Elven and Elvebakk 1996.

${ }^{3}$ Reference: Elven and Elvebakk 1996.

${ }^{4}$ Reference: Kojima and Wada 1999, Saville 1964.

singly. Higher percentage of plant cover was characteristic for more stable substrate where older individuals forming bigger cushions were common. In Zone $2 \mathrm{~b}$ the patchiness was more evident. In the open areas of mostly fine textured substrate vegetation was formed in poorly defined, loosely arranged assemblages and some individuals were growing singly. Sheltered terrain 
depressions were occupied by vegetation patches while exposed ridges with coarse material were rather bare.

Almost all of the plots in Zone 3 had a uniform plant cover. Gaps of bare ground occurred only on exposed ridges, cracks of humus layer or surface eroded by intense wash-out. Saxifraga oppositifolia, Dryas octopetala and Salix polaris were dominant within all study sites but coexisting with other species. Only Cassiope tetragona formed large patches, thoroughly superseding other species. Bryophytes were dominant in water seepage areas at the foot of the slopes and melting snow bedded surfaces.
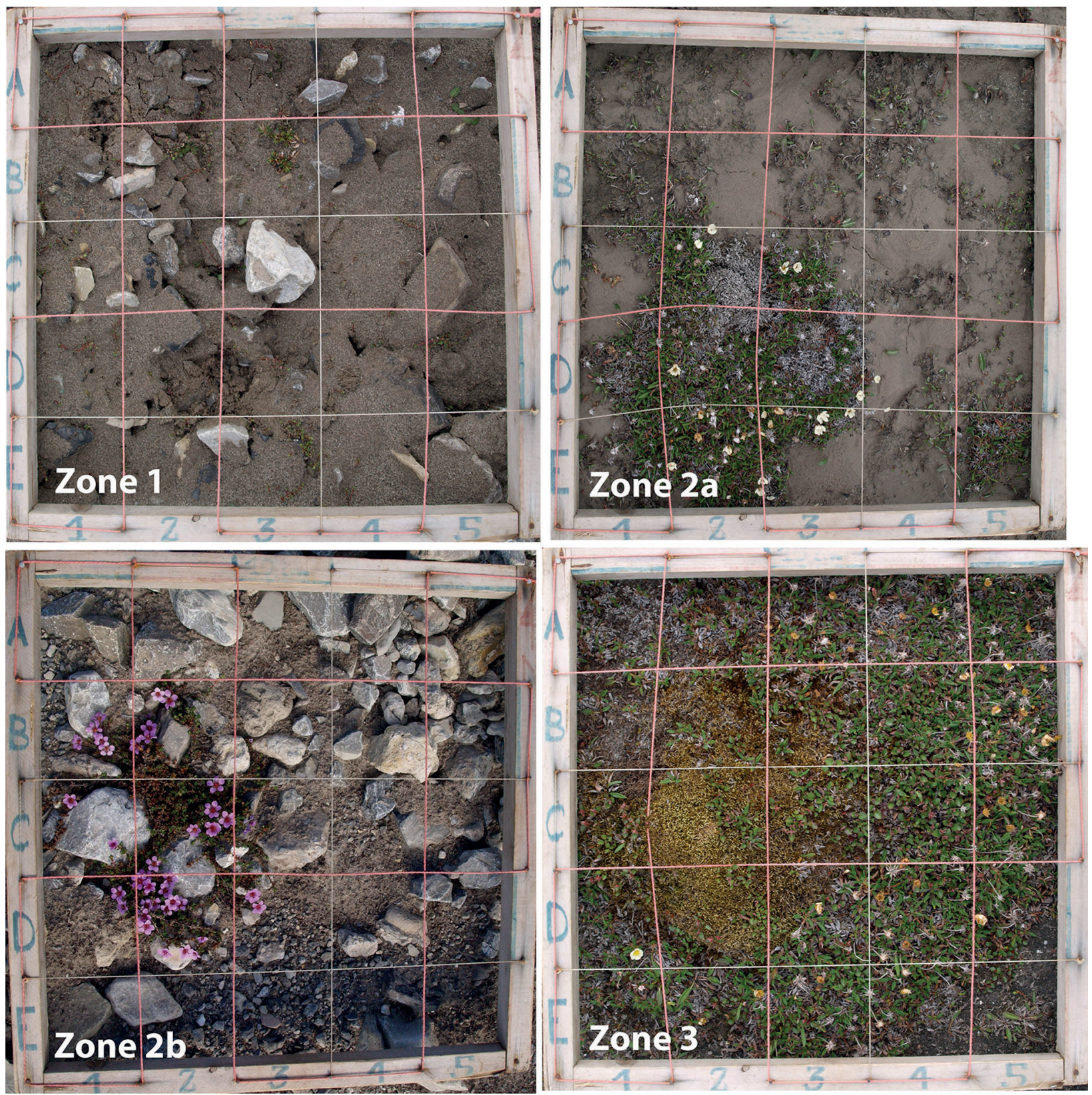

Fig. 2. Example of sample plots from delimited zones - differences in vegetation cover. 
average rate of herbs and dwarf shrubs was 14 and $11 \%$ respectively. Mosses and lichens were documented sporadically.

Characteristic for Zone 3 was high percentage of mosses in both moist and quite dry sites. Moss cover in several sample plots reached up to $20 \%$. Ground lichens were also documented. Dwarf shrub cover reached up to $55 \%$ in several sampling plots.

\section{Discussion}

\section{Colonisation potential}

Species of the Ebba Valley which proved to have the greatest potential for colonization are: Bistorta vivipara, Salix polaris and Saxifraga oppositifolia. These three species occur in all the sites along the transect. Dwarf shrubs such as Salix polaris had well developed root systems and many of them reaches the age of several decades (Buchwał et al. 2013). Marcante et al. (2009) points out that survival of adult perennials of this type serves as a buffer against temporal variations. This has particular relevance in disturbed habitats as a factor facilitating stabilisation of populations and their increase in size. It gives in Ebba Valley a possibility for establishing to species characteristic for later successional stages, as Bistorta vivipara. According to Hodkinson et al. (2003), this species is typical for the final stages of succession, yet it was present within almost all sampling plots. Its prevalence in the whole profile of the valley results most probably from high tolerance to environmental stress and high reproduction ability. B. vivipara is often reported to have the highest seedling density in both intact and disturbed habitats (e.g. Cooper et. al 2004) and the results from the study area agree with suggestions made in literature.

Saxifraga oppositifolia was present within all the plots of the transect and dominant in most of them. It is a pioneer species within its entire geographical range (Pirożnikow 1996). Saxifraga oppositifolia is resilient to being covered by fine sediments and colonizes new terrains by producing single long shoots (prostrate form) instead of forming a cushion (Kume et al. 1999). This prostrate form was observed in the majority of sample plots in Zone 1. Creeping stems allowed it to expand and to find places sheltered from winds. Most individuals also developed secondary root systems, allowing for a fuller use of resources and better anchorage in the substrate. Other characteristics of the species as a very high growth rate, often self-compatibility, substantial regeneration capacity and longevity of up to 25 years (Pirożnikow 1996) also contribute to its high abundance in the study area.

The main pioneer species in alluvial areas and in the vicinity of watercourses was Saxifraga aizoides, present only on moist or wet habitats and prevailing in all plots on which it was observed.

Species of lower abundance characteristic for later stages of succession were Dryas octopetala, Deschampsia alpina and Silene furcata. Deschampsia alpina occurred in large numbers only on moist soils, with a high proportion of fine-grained sediments. Dryas octopetala being a specialized species was documented only in calcareous habitats. Carex rupestris and Cassiope tetragona were species of significant coverage on moist and relatively fertile sites. They were characteristic for mature stages of succession. Cassiope tetragona locally occupied the areas of several square meters. Other taxa occurred sporadically and were highly dispersed. The spatial arrangement of vegetation and its structure depends in Ebba Valley on local chronosequence, but it is mainly a result of ecological limits imposed by local environmental conditions and by the destructive disturbances of the environment. The dispersal of other taxa may be a result of poorer tolerance to environmental stress and limitations or lack of safe, stable places, as they are not crucial for germination but are crucial for establishment (Marcante et al. 2009).

\section{Successional stages}

On the basis of the collected data on the number of species within sampling plots and their abundance and/or dominance determined on the grounds of space occupancy and shoot density, the attempt to distinguish successional stages in the Ebba Valley has been made. The age of landforms documented for the valley (Kłysz 1985, 1989, Long et al. 2012, Rachlewicz and Szczuciński 2013, van der Meij et al. 2016) and indicator species were also taken into account in the case, as well as disturbance regime, soil depth and moisture regime. In Ebba Valley, three 
stages of succession may be specified. There is a clear correspondence between increasing surface age, distance from the glacier and the increase in vegetation cover (Table 2). The increasing total number of species and the mean number of species within the sample plots, along with increasing percent of covered ground and shoot density confirms in this case chronosequential occurrence of plants from upper to lower stream of the river. This successional sequence refers also to the concept of geosuccession developed for Antarctic oases by Zwoliński (2007).

As sites covered by vegetation in an initial stage of development in the Ebba Valley can be considered these which were characterized by:

- number of species $</=4$, without occurrence of Cassiope tetragona,

- short distance to the glacier snout and terrain disturbances conditioned by its vicinity

- strong wind action

- expiry of less than 600 years since the glacier recession,

- vegetation cover of up to $10 \%$,

- presence of specialized species,

- presence of species characteristic for the initial stage of succession, such as: Saxifraga oppositifolia, Saxifraga aizoides and Salix polaris (Hodkinson et al. 2003, Raffl et al. 2006).

Such features were characteristic for all the plots in Zone 1 and 50\% in Zone 2. The later deglaciated area and more reworked by active geomorphic processes, the higher percentage of bare ground was observed (Fig. 3). Plant succession begins in such environments almost immediately

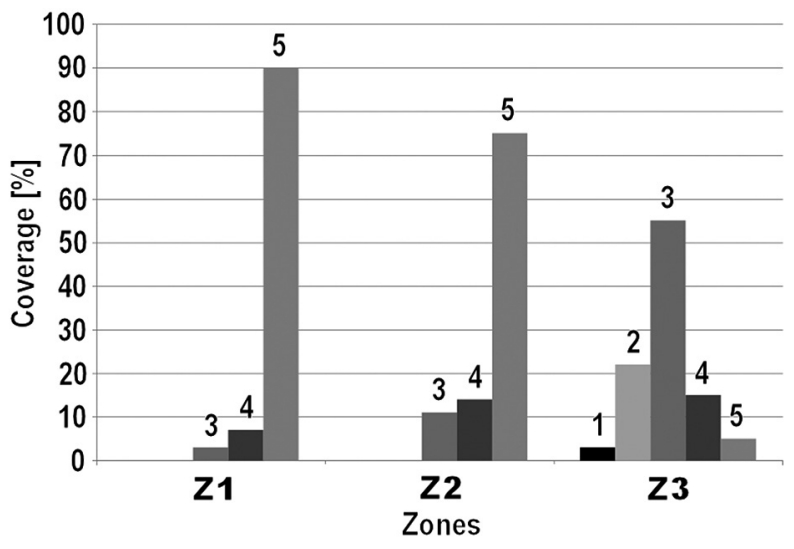

Fig. 3. Vertical vegetation structure.

1 - ground lichens, 2 - mosses, 3 - dwarf shrubs, 4 - herbs, 5 - bare ground. after deglaciation (Matthews 1992). In Z1 and parts of Z2 disturbance events repeatedly destroy existing plant cover and secondary plant colonisation takes place. Establishing of vegetation cover is highly dependent on microsite conditions, especially on the presence of undisturbed sites, sheltered from wind activity and runoff ("safe sites", as defined in Jumpponen et al. 1999). The main factor limiting plant colonisation in this area, except for geomorphic disturbances, is rapidly changing moisture conditions, from wet and moist at the beginning of vegetation season to very dry towards its end. Strong wind action has also a negative influence on plant establishment within this area - it causes mechanical injuries and burial in carried sediments, while cold air from the glacier combined with intense radiation on soil surface cause extreme fluctuations in soil temperature and desiccation (Jumpponen et al. 1999).

As the intermediate level of tundra development in the Ebba Valley can be considered sites characterized by:

- number of species from 5 to 7, without occurrence of Cassiope tetragona,

- expiry of about 2000-600 years since glacier recession,

- degree of vegetation cover in range of $25-75 \%$,

- presence of dominant species (representing over $45 \%$ of documented vegetation cover),

- presence of species characteristic for the intermediate stage of succession, such as Cerastium arcticum and Minuartia rubella (Hodkinson et al. 2003),

- visible blue-green algae and lichens on the substrate.

Such features were characteristic for $50 \%$ of the plots in Zone 2 and 15\% in Zone 3. In Zone 2 it is intense wind activity having influence on the development of plant cover. Winds sweep down from the glacier, carrying away fine textured sediments from the moraines, glacifluvial surfaces and instabilised areas of Zone 1. Zone $2 \mathrm{a}$ is the area where sand and silt is being accumulated. Most of the sites where succession stage can be considered as intermediate were found in this subzone. In Zone $2 \mathrm{~b}$ debris pavement is being exposed. Coarse textured, permeable substrate prevents germination while cold and strong winds have destructive impact on already growing plants. Despite the longer distance from 
the glacier and increasing terrain age, succession in Z2b may be in many places characterised as initial.

The characteristics of the mature or close to mature stage in Ebba Valley are:

- amount of species that excess 10, one of which is Cassiope tetragona, considered as a determinant of mature communities in the investigated area (Elvebakk 1999, Ohtsuka et al. 2006),

- expiry of at least 4000 years since the glacier recession and relative sediment cover stability,

- degree of vegetation cover in the range of 75 $-100 \%$,

- presence of the dominant species, but not exceeding $45 \%$,

- presence of species characteristic for advanced stages of succession, such as: Cassiope tetragona, Dryas octopetala and Pedicularis hirsuta (Hodkinson et al. 2003).

This successional stage was observed in $85 \%$ of sample plots in Zone 3. The total development time of the vegetation cover in the region of Isfjorden on raised marine terraces is, according to Tishkov (1986), from 3000-3500 years. Given that the marine terraces within this zone are considered to be older (Kłysz 1985, 1989, Long et al. 2012, Rachlewicz and Szczuciński 2013, van der Meij et al. 2016) along with the fact that Cassiope tetragona was observed, and even dominating within several sample plots, vegetation here should be considered as fully developed. However, only a few sites within the $\mathrm{Z3}$ area can be considered as mature due to local disturbances.

\section{Succession type}

On the basis of the abovementioned facts, the type of succession in the Ebba Valley can be determined (according to the nomenclature proposed by Svoboda and Henry 1987) as direction$\mathrm{al}$, non-replacement. The progress of this type of succession is characterized by the coexistence of species and quantitative expansion in its successional stages. Species do not replace each other, but those typical for later successional stages start to accompany the pioneer ones. In the studied area, the total number of shoots per $0.5 \mathrm{~m}^{2}$ and percentage of plant cover increased towards mature stages of succession in Zone 3 (Table 2). Species colonizing areas lately released from the ice cover in the Ebba Valley were Saxifraga oppositifolia, Salix polaris and Bistorta vivipara. They were not replaced by other species but gradually began to be accompanied by Dryas octopetala, Draba sp. and Silene furcata. All these species also occurred in the plots within Zone 3, where the succession has nearly reached a mature stage, and were accompanied by Cassiope tetragona, Carex misandra and Carex rupestris.

\section{Disturbance regime}

Although the general impression of the succession in Ebba Valley as being linear and consistent with time and distance from the glacier, many discontinuities have been observed. Investigation of sample plots within homogenous sites (at the first sight) proves that calling into question the chronosequence approaches which "are based on the implicit assumption that spatial and temporal variations are equivalent" (Pickett 1989, Rydgren et al. 2014:1367) is well justified. Matthews (1978) and Whittaker (1989) emphasize that other variables than time and distance from the glacier may play the main role in creating vegetation spatial pattern. Also Rydgren et al. (2014) proves that terrain age is not the main factor that explains present-day variation in species composition but local environmental variables may be more deterministic for vegetation structure. This also seems to be the case in Ebba Glacier foreland within all the zones. In Z1, the plots situated in the vicinity of outwash channels were characterized by slightly higher rates of plant cover and shoot density, which suggest that water availability is the most important factor influencing variation of vegetation cover. However, the plots located on waterlogged substrate, often disturbed by intense wash-out, were characterised by higher rate of bare ground.

Within the Z2, the influence of local environmental factors and disturbance regime is most explicit. Differentiation between fine-grained and moist substrate in Z2a and coarse, well-drained and desiccated by wind activity substrate in Z2b, is the most important cause of delimiting the two subzones, where successional stages are nonlinear with terrain age and distance from the glacier. Vegetation cover is much more developed on younger terrain of Z2a, again suggesting that moisture conditions and grain size of the 
substrate have crucial role for plant establishment. In $\mathrm{Z} 2 \mathrm{~b}$, the destructive influence of winds from the glacier causes that better developed vegetation is restricted to sheltered sites.

Within considerable parts of the $\mathrm{Z3}$ it can be observed that soil movements caused by repeated freeze-thaw cycles in active layer of permafrost area result in destroying root systems. Root tension caused by such movements may be a significant stress factor for plants (Scurfield 1973, Zoltai 1975, Schweingruber and Poschlod 2005) and limit the establishment of vegetation. Frost creep, which is the main stress factor for existing vegetation cover, causes death of plants in case of severe root injuries or root tension. The occurrence of water seepage areas at the foot of the terrace slopes and accumulation of snow melting water in terrain depressions in the form of tundra lakes (Zwoliński et al. 2008b, Mazurek et al. 2012) also lead to transformation of existing plant cover. Thus, it should be concluded that most of the area undergoes periglacial reworking and vegetation cover is still being transformed at many sites.

\section{Concluding remarks}

The major determinant of the degree of development of tundra vegetation is the time since the release of land from the glacier ice cover and stabilization of sediment cover. However, there is also a number local factors that can influence the linear development of plant cover, such as climate, substrate features as parent material, nutrient availability, $\mathrm{pH}$, moisture content, particle size variability, landform differentiation, and geomorphic activity. The results from Ebba Valley confirm previous studies on the subject, but also indicate that more attention should be paid to geomorphic activity as a factor disturbing chronosequences. Initiation of plant colonization may be delayed and linear chronosequences of plant succession may be disturbed mainly by high geomorphic activity, especially cryoturbation, mass movements and fluvial processes. Within sites of well-developed vegetation cover, such disturbances cause severe damages in it and result in patchiness: within dense tundra cover some sites are characterized by initial succession stages and where plant re-development is also affected by surrounding vegetation. Future studies on the relationship between geomorphic processes and succession should focus on combining phytosociological data with quantitative geomorphological studies on the intensity of the processes.

\section{References}

ACIA, 2004. Arctic climate impact assessment. Cambridge University Press, Cambridge, UK, Impact of a Warming Arctic.

Anderson D.G., Bliss L.C., 1998. Association of plant distribution patterns and microenvironments on patterned ground in a Polar Desert, Devon Island, N.W.T., Canada. Arctic and Alpine Research 30: 97-107.

Braun-Blanquet J., 1964. Pflanzensoziologie. Springer Verlag, Wien, New York.

Buchwał A., Rachlewicz G., Fonti P., Cherubini P., Gärtner H., 2013. Temperature modulates intra-plant growth of Salix polaris from a high Arctic site (Svalbard). Polar Biology 36: 1305-1318.

Cannoe N., Guglielmin M., Gerdol R., 2004. Relationships between vegetation patterns and periglacial landforms in northwestern Svalbard. Polar Biology 27: 562-571.

Chapin F.S., Sturm M., Serreze M.C., McFadden J.P., Key J.R., Lloyd A.H., McGuire A.D., Rupp T.S., Lynch A.H., Schimel J.P., Beringer J., Chapman W.L., Epstein H.E., Euskirchen E.S., Hinzman L.D., Jia G., Ping C.L., Tape K.D., Thompson C.D.C., Walker D.A., Welker J.M., 2005. Role of land-surface changes in Arctic summer warming. Science 310: 657-660. doi:10.1126/science.1117368

Chapin F.S., Walker L.R, Fastie CH.L, Sharman L.C., 1994. Mechanisms of Primary Succession Following Deglaciation at Glacier Bay, Alaska. Ecological Monographs 64(2): 149-175.

Churchill E.D., Hanson H.C., 1958. The concept of climax in arctic and alpine vegetation. Botanical Review 24: 127-191.

Connell J.H., Slayter R.O., 1977. Mechanisms of succession in natural communities and their role in community stability and organization. American Naturalist 111: 1119-1144.

Cooper E.J, Alsos I.G., Hagen D., Smith F.M., Coulson S.J., Hodkinson I.D., 2004. Plant recruitment in the High Arctic: Seed bank and seedling emergence on Svalbard. Journal of Vegetation Science 15: 115-224.

Dallmann W.K., Piepjohn K., Blomeier D., 2004. Geological map of Billefjorden, central Spitsbergen, Svalbard, with geological excursion guide. Norsk Polarinstitutt Temakart 36. Tromsø: Norwegian Polar Institute

Elvebakk A., 1999. Bioclimate delimitation and subdivisions of the Arctic. In: I. Nordal, V.Y. Razzhivin (eds) The species concept in the high north - A panarctic flora initiative. The Norwegian Academy of Science and Letters: 81-112.

Elven R., Elvebakk A. 1996. Vascular plants. In: A. Elvebakk, P. Prestrud (eds) A catalogue of Svalbard plants, fungi, algae and cyanobacteria. Norwegian Polar Institute, Oslo: 9-55.

Fleming K.M., Dowdeswell J.A., Oerlemans J., 1997. Modelling the Mass Balance of Northwest Spitsbergen Glaciers and Responses to Climate Change. Annals of Glaciology 24: 203-210.

Forbes B.C., Fauria M.M., Zetterberg P., 2010. Russian Arctic warming and 'greening' are closely tracked by tun- 
dra shrub willows. Global Change Biology 16: 1542-1554. doi:10.1111/j.1365-2486.2009.02047.x

Hodkinson I.D., Coulson S.J., Webb N.R., 2003. Community assembly along proglacial chronosequences in the high Arctic: vegetation and soil development in north - west Svalbard. Journal of Ecology 91: 651-663.

IPCC, 2013: Vaughan D.G., Comiso J.C., Allison I., Carrasco J., Kaser G., Kwok R., Mote P., Murray T., Paul J., Ren J., Rignot E., Solomina O., Steffen K., Zhang T. Observations: Cryosphere. In: T.F. Stocker, D. Qin, G.- K. Plattner, M.Tignor, S.K. Allen, J. Boschung, A. Nauels, Y. Xia, V. Bex and P.M. Midgley (eds). Climate Change 2013: The Physical Science Basis. Contribution of Working Group I to the Fifth Assessment Report of the Intergovernmental Panel on Climate Change. Cambridge University Press, Cambridge, United Kingdom and New York, NY, USA: 317-382.

Jenny H., 1980. The soil resource: Origin and behaviour. Springer Verlag, New York.

Jones G.A., Henry G.H.R., 2003. Primary plant succession on recently deglaciated terrain in the Canadian High Arctic. Journal of Biogeography 30(2): 277-296.

Jónsdóttir I.S., 2005. Terrestrial ecosystems on Svalbard: heterogeneity, complexity and fragility from an Arctic island perspective. Biological Environment: Proceedings of the Royal Irish Academy 105B: 155-165.

Jumpponen A., Väre H., Mattson K.G., Ohtonen R., Trappe J.M., 1999. Characterisation of safe sites for pioneers in primary succession on recently deglaciated terrain. Journal of Ecology 87: 98-105.

Kłysz P., 1985. Glacial relief and deposits of Ebba Glacier and its foreland (Petuniabukta region, Spitsbergen). Polish Polar Research 6(3): 283-299.

Kłysz P., Lindner L., Marks L., Wysokiński L., 1989. Late pleistocene and holocene relief modelling in the Ebbadalen - Nordenskjöldbreen region in Olav V Land, Central Spitsbergen. Polish Polar Research 10(3): 277-301.

Kojima S., Wada N., 1999. Ecological characterization of some selected vascular species in the arctic environment of $\mathrm{Ny}$ - Ålesund, Svalbard, in relation to soil moisture conditions. Polar Bioscience 12: 76-86.

Komárková V., 1993. Vegetation type hierarchies and landform disturbance in arctic Alaska and alpine Colorado with emphasis on snowpatches. Vegetatio 106: 155-181.

Kostrzewski A., Kaniecki A., Kapuściński J., Klimczak R., Stach A., Zwoliński Zb., 1989. The dynamics and rate of denudation of a glaciated and an unglaciated catchments, Central Spitsbergen. Polish Polar Research 10(3): 317-367.

Kostrzewski A., Mizgajski A., Zwolinski Zb., 2006. Typology of Cross-Boundary Fluxes of Mineral Matter Between Geoecosystems of Ebbadalen, Central Spitsbergen. Fourth ESF SEDIFLUX Science Meeting and First Workshop of I.A.G./ A.I.G. SEDIBUD, Trondheim: 52.

Kume A., Nakatsubo T., Bekku Y., Masuzawa T., 1999. Ecological significance of different forms of purple saxifrage, Saxifraga oppositifolia L., in the high arctic, Ny-Ålesund, Svalbard. Arctic, Antarctic and Alpine Research 31(1): 2733.

Long, A.J, Strzelecki, M.C., Lloyd, J.M., Bryant, C., 2012. Dating High Arctic Holocene relative sea level changes using juvenile articulated marine shells in raised beaches. Quaternary Science Reviews 48: 61-66.

Marcante S., Winkler E., Erschbamer B., 2009. Population dynamics along a primary succession gradient: do alpine species fit into a demographic succession theory? Annals of Botany 103(7): 1129-1143.
Matthews J.A., 1978. Plant colonisation patterns on a gletschervorfeld, southern Norway: a meso-scale geographical approach to vegetation change and phytometric dating. Boreas 7: 155-178.

Matthews J.A., 1992. The Ecology of Recently Deglaciated Terrain: A Geo-ecological Approach to Glacier Forelands and Primary Succession. Cambridge University Press, Cambridge.

Mazurek M., Paluszkiewicz R., Rachlewicz G., Zwoliński Zb., 2012. Variability of Water Chemistry in Tundra Lakes, Petuniabukta Coast, Central Spitsbergen, Svalbard. TheScientificWorldJournal: 1-13. doi:10.1100/2012/596516.

Mercier D., Étienne S., Sellier D., André M.-F., 2009. Paraglacial gullying of sediment mantled slopes: a case study of Colletthøgda, Kongsfjorden area, West Spitsbergen (Svalbard). Earth Surface Processes and Landforms 34(13): 1772-1789.

Moreau M., Laffly D., Joly D., Brossard T., 2005. Analysis of plant colonisation on an arctic moraine since the end of the Little Ice Age using remotely sensed data and a Bayesian approach. Remote Sensing of Environment 99(3): 244-253.

Moreau M., Mercier D., Laffly D., Roussel E., 2008. Impacts of recent paraglacial dynamics on plant colonization: A case study on Midtre Lovénbreen foreland, Spitsbergen $\left(79^{\circ} \mathrm{N}\right)$. Geomorphology 95: 48-60.

Natali S.M., Schuur E.A.G., Rubin R.L., 2012. Increased plant productivity in Alaskan tundra as a result of experimental warming of soil and permafrost. Journal of Ecology 100: 488-498.

Nordli Ø., Przybylak R., Ogilvie A., Isaksen K., 2014. Longterm temperature trends and variability on Spitsbergen: the extended Svalbard Airport temperature series, 18982012. Polar Research 33, doi: 10.3402/ polar.v33.21349.

Ohtsuka T., Adachi M., Uchida M., Nakatsubo T., 2006. Relationships between vegetation types and soil properties along a topographical gradient on the northern coast of the Brøgger Peninsula, Svalbard. Polar Bioscience 19: 63-72.

Pickett S.T.A., 1989. Space-for-time substitution as an alternative to long-term studies. In: Likens, G.E. (ed.) Longterm studies in ecology. Springer, New York, US, 110-135.

Pirożnikow E., 1996. Strategie adaptacyjne roślin w warunkach pustyń arktycznych. Białystok 1996.

Prach K., Rachlewicz G., 2012. Succession of vascular plants in front of retreating glaciers in central Spitsbergen. Polish Polar Research 33(4): 319-328.

Prach K., Klimešová J., Košnar J., Redčenko O., Hais M., 2012. Variability of contemporary vegetation around Petuniabukta, central Spitsbergen. Polish Polar Research 33(4): 383-394.

Rachlewicz G., 2003. Warunki meteorologiczne w zatoce Petunia (Spitsbergen środkowy) w sezonach letnich $2000 \mathrm{i}$ 2001. Problemy Klimatologii Polarnej 13: 127-138.

Rachlewicz G., Kostrzewski A., Marciniak M., Szpikowski J., Zwoliński Zb., 2012. The function of contemporary physical geography processes in polar regions. In: P.Churski (ed.), Contemporary Issues in Polish Geography, Bogucki Wydawnictwo Naukowe, Poznań: 95-110.

Rachlewicz G., Styszyńska A., 2007. Porównanie przebiegu temperatury powietrza w Petuniabukta i Svalbard-Lufthavn (Isfjord, Spitsbergen) w latach 2001-2003. Problemy Klimatologii Polarnej 17: 121-134. 
Rachlewicz G., Szczuciński W., 2008. Changes in permafrost active layer thermal structure in dry polar climate (Petuniabukta, Svalbard). Polish Polar Research 29(3): 261-278.

Rachlewicz G., Szczuciński W., 2013. Raised marine terraces in the vicinity of the north part of Billefjorden. In: Zwoliński Z., Kostrzewski A., Pulina M. (eds.) Ancient and modern geoecosystems of Spitsbergen - Polish geomorphological research. Bogucki Wydawnictwo Naukowe, 379-389.

Rachlewicz G., Szczuciński W., Ewertowski M., 2007. Post "Little Ice Age” retreat rates of glaciers around Billefjorden in central Spitsbergen, Svalbard. Polish Polar Research 28(3): 159-186.

Rachlewicz G., Szpikowska G., Szpikowski J., Zwoliński $\mathrm{Zb}$., 2016. Solute and particulate fluxes in catchments in Spitsbergen. In: Beylich A.A., Dixon J.C., Zwoliński Zb., Source-to-Sink Fluxes in Undisturbed Cold Environments. Cambridge University Press: 133-143.

Rachlewicz G., Zwoliński Zb., Kostrzewski A., Birkenmajer K., 2013. Geographical environment in the vicinity of the Adam Mickiewicz University in Poznań Polar Station Petuniabukta. In: Zwoliński Zb., Kostrzewski A., Pulina M., (eds.), Ancient and modern geoecosystems of Spitsbergen. Polish geomorphological research. Bogucki Wydawnictwo Naukowe, Poznań: 199-237.

Raffl C., Marcante S., Erschbamer B., 2006. The role of spontaneous selfing in the pioneer species Saxifraga aizoides. Flora 202: 128-132.

Robotnov T.A., 1964. Determination of age composition of species populations in a community. Polevaya Geobotanika 3: 132-208 (in Russian).

Rydgren K., Halvorsen R., Töpper J.P, Njøs J.M., 2014. Glacier foreland succession and the fading effect of terrain age. Journal of Vegetation Science 25: 1367-1380

Rønning O. I., 1996. The flora of Svalbard. Norsk Polarinstitutt, Oslo.

Saville D.B.O., 1964: General ecology and vascular plants of the Hazen Camp area. Arctic 17: 237-258.

Schweingruber F.H., Poschlod P., 2005. Growth rings in herbs and shrubs: life span, age determination and stem anatomy. Forest Snow and Landscape Research 79: 195-415.
Scurfield G., 1973. Reaction wood: its structure and function. Science 179: 647-655.

Svoboda J., Henry G.H.R., 1987. Succession in marginal arctic environments. Arctic and Alpine Research 19(4): 373-384.

Szpikowski J., Szpikowska G., Zwoliński Z., Rachlewicz G., Kostrzewski A., Marciniak M., Dragon K., 2014. Character and rate of denudation in a High Arctic glacierized catchment (Ebbaelva, Central Spitsbergen). Geomorphology 218: 52-62.

Tishkov A.A., 1986: Primary succession in arctic tundra on the west coast of Spitsbergen (Svalbard). Polar Geography and Geology 10: 148-156.

van der Meij W.M., Temme A.J.A.M., de Kleijn C.M.F.J.J., Reimann T., Heuvelink G.B.M., Zwoliński Zb., Rachlewicz G., Rymer K., Sommer M., 2016. Arctic soil development on a series of marine terraces on Central Spitsbergen, Svalbard: a combined geochronology, fieldwork and modelling approach. SOIL 2: 221-240.

Whittaker R.H., 1989. The vegetation of the Storbreen gletshervorfeld, Jotunheimen, Norway. III. Vegetation-environment relationships. Journal of Biogeography 16: 413433.

Zoltai S.C., 1975. Tree ring record of soil movements on permafrost. Arctic and Alpine Research 7(4): 331-340.

Zwoliński Zb., 2007. Mobilność materii mineralnej na obszarach paraglacjalnych, Wyspa Króla Jerzego, Antarktyka Zachodnia. Wydawnictwo Naukowe UAM, Ser. Geografia 74: 1-266.

Zwoliński Zb., Dobiński W., 2008. Recesja lądolodów i lodowców oraz degradacja wieloletniej zmarzliny. Kosmos 57(3-4): 209-224.

Zwoliński Z., Kostrzewski A., Rachlewicz G., 2008a. Environmental Changes in the Arctic. In: Singh S., Starkel L., Syiemlieh H.J. (eds) Environmental Changes and Geomorphic Hazards. Bookwell, Delhi, India: 23-36.

Zwoliński Z., Mazurek M., Paluszkiewicz R., Rachlewicz G., $2008 \mathrm{~b}$. The matter fluxes in geoecosystem of small tundra lakes, Petuniabukta coast, Billefjorden, Central Spitsbergen. Zeitschrift fur Geomorphologie 52(1): 79-101. 